ISSN 2089-8673

\title{
Pemilihan Komponen Arsitektur Untuk Penentuan Posisi Pengunjung Pada Sistem Pemandu Museum
}

\author{
Eko Suripto Pasinggi, Selo Sulistyo, Bimo Sunarfri Hantono \\ e-Systems Lab, Jurusan Teknik Elektro dan Teknologi Informasi \\ Universitas Gadjah Mada \\ Yogyakarta, Indonesia \\ ekosuripto_s2te12@mail.ugm.ac.id, selo@ugm.ac.id,bhe@ugm.ac.id
}

\begin{abstract}
Sistem pemandu museum merupakan salah satu penerapan teknologi informasi (TI) pada museum yang diharapkan dapat membantu pengunjung menelusuri museum. Untuk dapat memberikan informasi yang sesuai, sistem pemandu membutuhkan informasi posisi pengunjung. Informasi posisi tersebut dapat diperoleh dari Sistem Penentuan Posisi (SPP). Teknologi Global Positioning System (GPS) sebagai standar SPP tidak cocok untuk diterapkan untuk lingkungan di dalam ruangan. Oleh sebab itu diperlukan SPP yang khusus bekerja di dalam ruangan. Untuk membangun sebuah SPP yang bekerja sesuai dengan lingkungan museum, diperlukan pemilihan komponen penyusun arsitektur yang berdasarkan pada kebutuhan dan kondisi museum. Studi kasus di Museum Sonobudoyo memberikan hasil bahwa arsitektur yang sesuai sebaiknya menggunakan teknologi WLAN dengan teknik scene analysis berbasis RSSI yang memberikan output berupa informasi posisi absolut.
\end{abstract}

Keywords-Museum, Positioning, Arsitektur, Sistem Penentuan Posisi, Pemandu

\section{PENDAHULUAN}

Museum merupakan suatu tempat yang digunakan sebagai tempat untuk mengoleksi, merawat dan memamerkan bendabenda yang patut mendapat perhatian umum, seperti peninggalan sejarah, seni, dan ilmu. Di Indonesia, wisata museum memiliki rata-rata jumlah pengunjung yang lebih sedikit dibandingkan dengan wisata alam, misalnya pantai dan gunung. Faktor yang menyebabkan rendahnya kunjungan tersebut adalah stigma masyarakat yang masih menganggap bahwa museum merupakan sebuah ruang pamer yang hanya digunakan untuk menyimpan benda-benda bersejarah dan kuno. Selain itu faktor daya tarik museum berupa infrastruktur dan fasilitas juga mempengaruhi hal tersebut. Proyek eMuseum digagas sebagai salah satu solusi permasalahan tersebut. Hasil yang diharapkan dari proyek ini berupa penerapan teknologi informasi (TI) sebagai fasilitas museum.
Penerapan TI pada museum dapat dilakukan pada beberapa hal, salah satu sistem yang diangkat dalam proyek ini adalah sistem pemandu museum. Sistem pemandu museum berfungsi untuk memandu dan memberikan informasi kepada pengunjung. Sistem ini dirancang untuk bekerja dengan cara memberikan informasi yang sesuai dengan posisi pengguna. Posisi merupakan salah satu konteks yang penting dan sering digunakan dalam berbagai sistem yang bersifat contextawareness [1].

Sistem pemandu museum harus mendapatkan informasi posisi yang akurat agar dapat melakukan fungsinya dengan benar. Oleh karena itu dibutuhkan sistem penentuan posisi (SPP) yang sesuai dengan lingkungan museum. Teknologi GPS merupakan sistem penentuan posisi yang paling luas digunakan saat ini dan menjadi sistem standar untuk penentuan posisi. GPS mampu memberikan tingkat akurasi yang tinggi untuk penggunaan di luar ruangan, namun tidak berfungsi maksimal untuk penggunaan di dalam ruangan [2],[3]. Oleh karena itu, GPS tidak cocok digunakan sebagai komponen sebuah sistem pemandu museum. Dengan demikian diperlukan sebuah sistem penentuan posisi yang khusus bekerja untuk lingkungan di dalam ruangan (indoor).

Salah satu tahap dalam membangun sebuah SPP adalah penyusunan arsitektur sistem tersebut, yang akan dibahas dalam paper ini. Proses yang dilakukan adalah mengidentifikasi kebutuhan dan kondisi lingkungan museum yang akan menjadi pertimbangan utama melakukan proses pemilihan tersebut.

Paper ini disusun dalam lima bab. Bab II akan menjelaskan mengenai arsitektur dan komponen SPP. Kemudian pada Bab III akan dilakukan pemilihan komponen yang akan digunakan berdasarkan pada beberapa pertimbangan. Dalam bab ini juga akan dijelaskan mengenai algoritme kNN yang akan digunakan. Beberapa ide dan tantangan yang ditemui dalam pengembangan sistem ini akan dibahas pada Bab IV. 


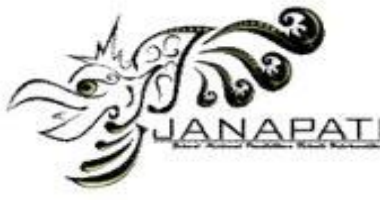

Kesimpulan dari pembahasan yang dilakukan pada bab-bab sebelumnya akan disimpulkan dalam Bab V.

\section{ARSITEKTUR SPP}

Secara umum, sistem penentuan posisi memiliki arsitektur dengan empat lapisan (output, parameter, teknik, dan teknologi) seperti yang ditunjukkan pada Gambar 1. Dalam hal ini, arsitektur merujuk pada komponen-komponen penyusun sebuah SPP. Pada tiap lapisan terdapat beberapa kemungkinan komponen yang digunakan.

SPP dapat menyediakan beberapa pilihan jenis informasi posisi sebagai keluaran output sesuai dengan kebutuhan. Informasi tersebut dapat berupa lokasi absolut, relatif atau proximity [4], [5], [6]. Informasi absolut dinyatakan dalam bentuk koordinat, misalnya koordinat $(x, y)$. Informasi relatif diperoleh berdasarkan referensi sebuah objek lain, misalnya objek A berada di sebelah kiri objek B. Informasi proximity dinyatakan bentuk simbolik, misalnya dapur, kantor, dan kelas. Sebuah sistem juga dapat mengkombinasikan jenis informasi untuk memperkaya informasi, misalnya sebuah lokasi absolut ditambah dengan informasi proximity sebagai tambahan informasi.

\begin{tabular}{|c|c|c|c|c|c|c|c|c|c|}
\hline Output & \multicolumn{2}{|c|}{ Posisi relatif } & \multicolumn{4}{|c|}{ Posisi absolut } & \multicolumn{3}{|c|}{ Proximity } \\
\hline Parameter & \multicolumn{2}{|l|}{$\mathrm{AOA}$} & \multicolumn{2}{|l|}{ TOA } & \multicolumn{2}{|c|}{ TDOA } & \multicolumn{3}{|c|}{ RSSI } \\
\hline \multirow{2}{*}{ Teknik } & \multirow{2}{*}{ Trilateration } & \multirow{2}{*}{ Triangulation } & \multicolumn{5}{|c|}{ Scene Analysis / Fingerprint } & \multirow{2}{*}{\multicolumn{2}{|c|}{ Proximity }} \\
\hline & & & kNN & Fuzzi & NN & SVM & SMP & & \\
\hline \multirow{2}{*}{ Teknologi } & \multirow{2}{*}{ Infrared } & \multirow{2}{*}{ Ultrasound } & \multicolumn{7}{|c|}{ Radio Frequency } \\
\hline & & & WL & AN & uetooth & RFID & & & Cellular \\
\hline
\end{tabular}

Gambar 1. Arsitektur umum SPP

\section{A. Parameter}

Parameter menyatakan sebuah karakteristik yang menjadi objek pengukuran untuk digunakan sebagai masukan pada proses komputasi. Dalam [4], [6], [7], dan [8] dikemukakan beberapa parameter yang dapat digunakan dalam SPP, yaitu:

1. AOA (Angle of Arrival): AOA merupakan besar sudut yang dibentuk oleh arah datang sebuah sinyal dengan sebuah arah referensi (misalnya arah Utara sebagai $0 \circ$ ).

2. TOA (Time of Arrival): TOA merujuk pada waktu propagasi sinyal (signal propagation time) dari titik asal ke titik tujuan atau dari titik asal hingga tiba dititik asal lagi. Teknik ini membutuhkan sinkronisasi waktu yang akurat antar titik.

3. TDOA (Time Difference of Arrival): Parameter ini diperoleh dari perbedaan TOA beberapa sinyal yang diterima. Teknik ini juga membutuhkan sinkronisasi waktu yang akurat.

4. RSSI (Recieve Signal Strengh Indication): Dalam perambatannya sebuah sinyal akan mengalami pelemahan kuat sinyal (signal propagation loss) yang sebanding
ISSN 2089-8673

Jurnal Nasional Pendidikan Teknik Informatika (JANAPATI)

Volume 3, Nomor 3, Desember 2014

dengan jarak. nilai tersebut dapat diperoleh dengan membandingkan kuat sinyal yang dipancarkan dengan kuat sinyal yang diterima.

\section{B. Teknik Penentuan Posisi}

Nilai parameter yang diperoleh dari pengukuran kemudian diolah dengan suatu teknik untuk memperoleh perkiraan posisi. Ada berbagai teknik yang dapat digunakan, namun ada empat teknik yang umum digunakan, yaitu:

1. Trilateration: Teknik ini menggunakan prinsip geometri untuk menghitung posisi sebuah titik berdasarkan jarak titik tersebut dengan beberapa titik (minimal 3 titik) yang diketahui posisinya seperti pada Gambar 2.

2. Triangulation: Triangulation merupakan teknik untuk menentukan posisi sebuah titik dengan cara menghitung sudut antar titik tersebut dengan kedua titik pada ujung sebuah garis yang diketahui posisi dan panjangnya seperti yang ditampilkan pada Gambar 3.

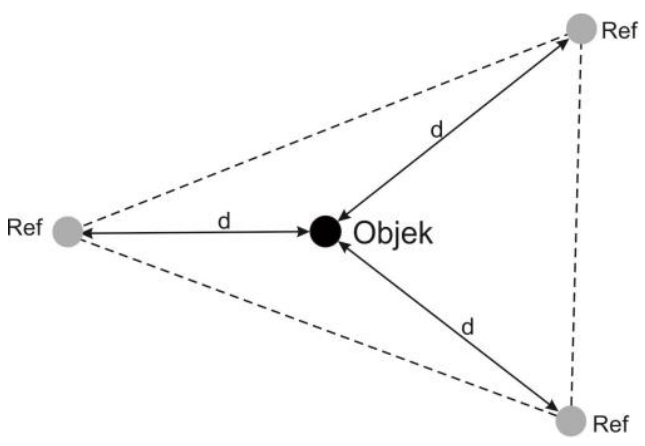

Gambar 2. Teknik trilateration

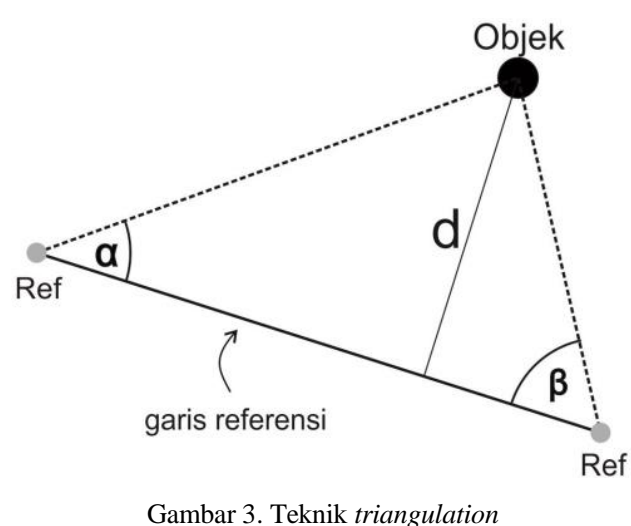

3. Scene Analysis/Fingerprint: Teknik ini menentukan posisi dengan cara melakukan perbandingan hasil pengukuran pada suatu titik dengan nilai pada beberapa titik sampel yang diketahui lokasinya. Titik-titik sampel tersebut disebut fitur atau fingerprint seperti yang ditunjukkan pada Gambar 4. Ada beberapa algoritme yang dapat digunakan untuk melakukan proses perbandingan tersebut, yaitu $k$ Nearest 
Neighboar (kNN), Fuzzy Logic, Neural Network (NN), Support Vector Machine (SVM), Smallest M-vertex Polygon (SMP).

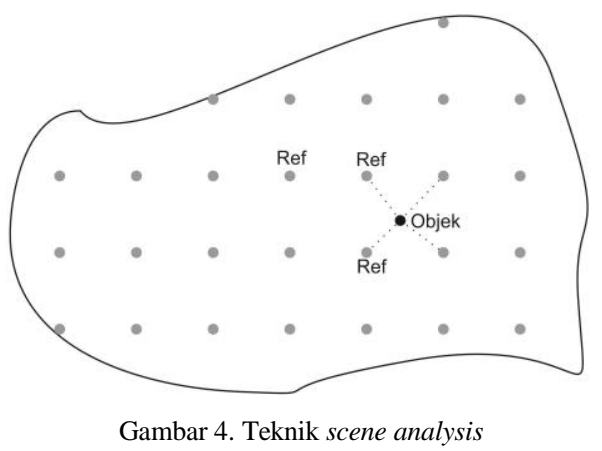

4. Proximity: Teknik proximity digunakan untuk menentukan area dimana sebuah titik berada. Sebuah titik dinyatakan masuk ke dalam sebuah area berdasarkan suatu parameter tertentu, misalnya, jarak terhadap titik referensi dan kuat sinyal. Pada Gambar 5, Objek 1 dinyatakan masuk ke dalam area sedangkan Objek 2 tidak.

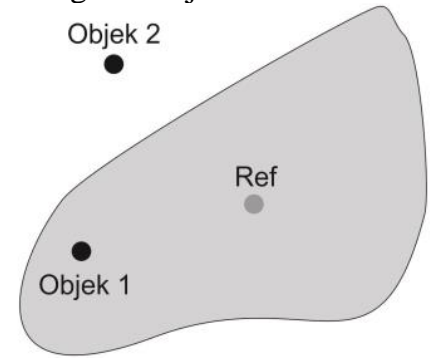

Gambar 5. Teknik proximity

\section{Teknologi}

Teknologi dalam arsitektur SPP merujuk pada infrastruktur yang digunakan sebagai dasar penentuan posisi. Dalam beberapa literatur dapat ditemukan teknologi-teknologi yang dapat digunakan sebagai infrastruktur SPP, antara lain:

1. Inframerah (Infrared) [9]: InfraRed merupakan gelombang eletromagnetik dengan panjang gelombang $700 \mathrm{~nm}-1 \mathrm{~mm}$ dan frekuensi $430 \mathrm{THz}$ - $300 \mathrm{GHz}$. Dalam bidang komunikasi infrared digunakan sebagai media transmisi. Teknologi infrared adalah generasi pertama dari teknologi koneksi nirkabel yang digunakan untuk perangkat mobile.

2. Ultrasonik (Ultrasound) [10]: Gelombang ultrasonik merupakan gelombang mekanik longitudinal dengan frekuensi di atas $20 \mathrm{kHz}$. Gelombang ini dapat dimanfaatkan dalam teknologi sensor. Sensor ini digunakan untuk mengetahui jarak suatu benda dengan sensor. Sensor tersebut bekerja menggunakan prinsip yang sama dengan yang dilakukan oleh kelelawar, yaitu dengan menerima pantulan gelombang yang dipancarkan dan menghitung jaraknya berdasarkan kecepatan rambat gelombang tersebut.
3. Radio frequency [8]: Gelombang radio merupakan golombang eletronik yang memiliki panjang gelombang 1 $\mathrm{mm}-10.000 \mathrm{~km}$ dan frekuensi $3 \mathrm{THz}$ - 3Hz. Beberapa teknologi nirkabel yang digunakan saat ini bekerja pada rentang frekuensi gelombang radio.

a. Bluetooth [11]: Teknologi Bluetooth bekerja pada frekuensi 2,4 GHz dengan jangkauan hingga $100 \mathrm{~m}$. Diaplikasikan pada berbagai perangkat untuk membangun Personal Area Network (PAN).

b. Teknologi WLAN (Wireless Local Area Network) [12]: WLAN bekerja pada frekuensi $2,4 \mathrm{GHz}$ dan 5 . GHz. Saat ini teknologi ini merupakan teknologi yang paling umum digunakan dan telah tertanam pada berbagai perangkat, khususnya perangkat mobile seperti laptop dan smartphone.

c. RFID (Radio Frequency Identification) [13]: RFID merupakan teknologi identifikasi yang memanfaatkan gelombang radio sebagai media transmisi. RFID terdiri dari RFID-tag dan RFID-reader. Setiap RFID-tag memiliki sebuah kode yang unik sebagai identitas yang dapat dibaca oleh RFIDreader dengan cara mengirimkan request. RFID bekerja pada berbagai panjang gelombang dengan jangkauan area hingga 200 $\mathrm{m}$.

d. WSN (Wireless Sensor Network) [14]: WSN merupakan sekumpulan perangkat sensor yang bersifat otonom dan untuk mengirimkan data membentuk suatu jaringan yang bersifat ad-hoc. WSN bekerja pada frekuensi 315, 868, 915, dan $2400 \mathrm{MHz}$.

Tidak semua kemungkinan kombinasi dari teknologi, teknik, parameter dan output dapat diterapkan untuk membangun suatu SPP [8]. Hal tersebut disebabkan oleh adanya keterbatasan tiap komponen serta kecocokan antar komponen pada lapisan yang berbeda. Sebagai contoh, teknik trilateration, triangulation, dan scene analysys mampu menyediakan ketiga jenis output sedangkan teknik proximity hanya dapat menyediakan jenis informasi proximity. Infrared memiliki jangkauan yang pendek sehingga hanya cocok untuk teknik proximity.

\section{STUDI KASUS: MUSEUM SONOBUDOYO}

Museum Sonobudoyo adalah museum sejarah dan kebudayaan jawa. Museum Sonobudoyo memiliki koleksi yang paling lengkap setelah museum Nasional, yaitu sekitar 43.000 koleksi dan selalu bertambah setiap tahunnya. Koleksinya dikelompokkan menjadi beberapa jenis, misalnya koleksi seni rupa, teknologi, geologi, biologi, arkeologi, dan historika.

Pemilihan komponen penyusun sebuah SPP dilakukan dengan berbagai pertimbangan, misalnya kebutuhan sistem, keadaan lingkungan, dukungan infrastruktur, biaya, dan kesulitan implementasi. Museum sebagai lokasi penerapan sistem yang akan dibangun dalam penelitian ini memiliki karakter khusus yang akan digunakan sebagai bahan pertimbangan pemilihan komponen. Berikut ini beberapa kondisi yang digunakan dalam pemilihan komponen SPP ini: 
1. Museum memiliki luas sekitar $7.867 \mathrm{~m}^{2}$. Potongan denah museum tersebut dapat dilihat pada Gambar 6 .

2. Bagian dalam museum dibagi menjadi ruang-ruang kecil dengan ukuran bervariasi (panjang sisi dari $5 \mathrm{~m}-13 \mathrm{~m}$ ).

3. Sebagian besar artefak museum dipajang di dalam lemari dengan ukuran bervariasi dari $1 \mathrm{~m}-2,5 \mathrm{~m}$.

4. Posisi lemari artefak dalam museum cenderung konstan.

5. Sistem pemandu museum yang akan dibangun berupa perangkat lunak yang dijalankan pada perangkat mobile.

6. Informasi yang disertakan dalam perangkat lunak akan diletakkan pada sebuah komputer server sehingga perangkat harus selalu terhubung jaringan.

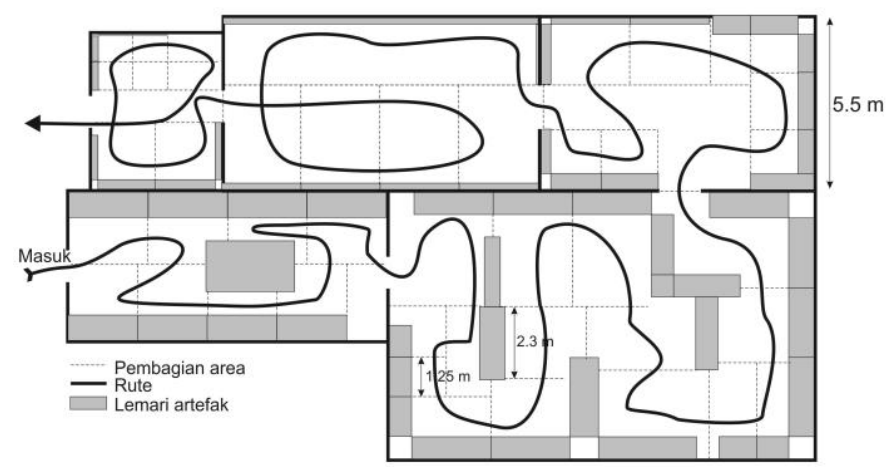

Gambar 6. Potongan denah Museum Sonobudoyo

Berdasarkan keadaan dan kebutuhan tersebut, komponen yang dipilih adalah sebagai berikut:

1. Teknologi: WLAN

Teknologi WLAN dipilih karena aplikasi pemandu museum tersebut akan digunakan pada perangkat mobile. Saat ini, sebagian perangkat mobile telah memiliki fitur WLAN, selain bluetooth yang juga menjadi pertimbangan. Dari sisi biaya, penggunaan WLAN merupakan pemanfaatan infrastruktur yang ada sehingga tidak memerlukan infrastruktur tambahan. SPP berbasis WLAN relatif lebih mudah untuk diterapkan pada perangkat mobile, karena telah mendukung teknologi WLAN, dibandingkan dengan teknologi RFID dan WSN yang membutuhkan perangkat tambahan untuk dapat dimanfaatkan pada perangkat mobile.

\section{Teknik: Scene analysis}

Bangunan museum yang terdiri dari beberapa ruangan dapat mengakibatkan adanya fenomena multipath pada sinyal yang dapat memperngaruhi pengukuran suatu parameter sinyal. Hal tersebut dapat diatasi oleh kelebihan yang dimiliki oleh teknik scene analyisis yang hanya melihat nilai parameter suatu titik tanpa memperdulikan kasus multipath.

3. Parameter: RSSI

Dari sisi kemudahan implementasi, RSSI relatif lebih mudah dibandingkan parameter lainnya. AOA membutuhkan penggunaan antena array yang berarti penambahan perangkat. TOA dan TDOA membutuhkan sinkronisasi waktu antar perangkat mobile dan access point (AP). Sinkronisasi tersebut membuat implementasi menjadi sulit karena membutuhkan akurasi yang tinggi dan juga karena sistem pemandu tersebut akan dijalankan pada masing-masing perangkat pengunjung museum.

4. Output: Posisi absolut

Output yang diharapkan dari SPP ini berupa posisi yang merujuk pada area-area kecil yang disesuaikan dengan ukuran artefak museum (Gambar 6). Tingkat akurasi yang diharapkan dari SPP ini tergantung dengan ukuran area tersebut, semakin kecil ukuran area maka dibutuhkan akurasi yang lebih tinggi. Penggunaan posisi relatif akan menimbulkan kerumitan implementasi karena museum memiliki area yang cukup luas dan juga jumlah artefak yang banyak.

\section{IDE DAN TANTANGAN PENGEMBANGAN}

Untuk meningkatkan kualitas SPP, khususnya akurasi, beberapa ide pengembangan yang akan dilakukan dan tantangan yang dihadapi antar lain:

1. Algoritme $\mathrm{kNN}$

Algoritme yang akan digunakan dalam teknik scene analysis ini adalah algoritme kNN. Algoritme kNN memiliki performa (akurasi dan presisi) yang lebih baik dari beberapa algoritme lainnya [15], [16]. Selain itu, kNN dapat menangani persoalan skalabilitas dan robustness. Kelemahan utama kNN adalah kompleksitas yang merujuk pada waktu komputasi yang dibutuhkan. Algoritme kNN membutuhkan waktu komputasi yang lebih besar dan meningkat sesuai dengan peningkatan jumlah titik sampel. Secara umum proses yang dilakukan dalam metode scene analysis terdiri dari dua fase, offline dan online (Gambar 7). pada fase offline dikumpulkan nilai fitur pada tiap titik sampel/ reference point (RP) dan dibentuk menjadi sebuah basis data (radio map). Pada fase online dilakukan perbandingan antara radio map dengan nilai parameter pada posisi yang akan ditentukan koordinatnya. Algoritme kNN diterapkan pada proses menentukan perbandingan tersebut.

Setiap data yang diambil dalam fase offline akan dinyatakan dalam bentuk $R P_{i}=\left(L_{i}, F_{i}\right)$, dengan nilai, $L i=\left(x_{i}, y_{i}\right)$ menyatakan posisi, $F_{i}=\left(R S S I_{i, l}, R S S I_{i, 2}, \ldots, R S S I_{i, j}\right)$ adalah sebuah vektor menyatakan nilai RSSI yang terukur, $i=1$, $2,3, \ldots, n$ menyatakan jumlah RP, dan $j=1,2,3, \ldots, m$ menyatakan jumlah AP. Sedangkan nilai yang diperoleh pada fase online dinyatakan dalam bentuk RSSI $=\left(R S S I_{1}\right.$, $\left.R S S I_{2}, \ldots, R S S I_{j}\right)$. Nilai sebuah RSSI sebuah AP yang tidak terbaca atau tidak menjangkau suatu titik akan diisi dengan nilai $N U L L$. 


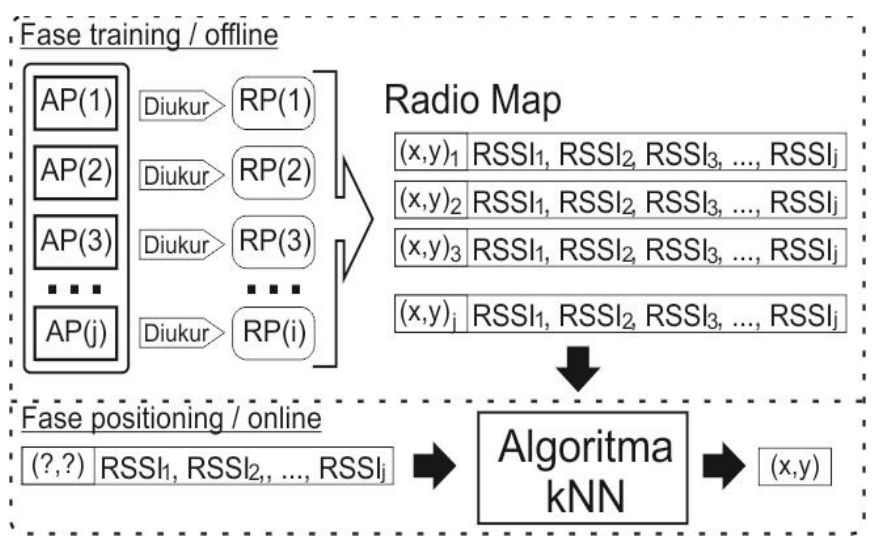

Gambar 7. Fase offline dan fase online pada teknik scene analysis

Algoritme kNN bekerja dengan menghitung jarak (distance) antar nilai pada fase online dengan nilai-nilai pada radio map. Penghitungan jarak ini menggunakan persamaan Euclidean Distance (1). Setelah itu akan diambil subset RP sebanyak $k$ berdasarkan nilai jarak yang terkecil.

$$
D_{i}=\sqrt{\sum_{j=1}^{n}\left(R S S I_{i, j}-R S S I_{j}\right)^{2}}
$$

Selanjutnya koordinat posisi tersebut dapat ditentukan dengan menghitung nilai rata-rata koordinat sejumlah $k$ nilai yang diambil tersebut dengan persamaan (2).

$$
(x, y)=\frac{1}{k} \sum_{i=1}^{k}\left(x_{i}, y_{i}\right)
$$

2. RP filtering

Pada bagian sebelumnya telah dijelaskan bahwa kelemahan algoritme kNN adalah waktu komputasi yang lebih besar. Salah satu usaha yang dapat dilakukan untuk mengurangi waktu komputasi adalah mengurangi jumlah data yang harus diolah. Data RP pada radio map dapat difilter sebelum digunakan dalam Persamaan (1). Acuan yang digunakan untuk filter adalah nilai RSSI pada fase online. Jika nilai RSSI yang diterima dari AP ke- $i$ tidak bernilai $N U L L$, maka nilai RSSI AP ke- $i$ pada RP yang dipilih juga tidak bernilai NULL.

3. Pengelompokan (clustering) RP

Usaha lain yang dapat dilakukan untuk mengurangi beban komputasi adalah melakukan pengelompokan RP. Beberapa RP dapat dikelompokkan berdasarkan kriteria tertentu. Kelompok RP yang akan digunakan dalam perhitungan diseleksi berdasarkan jarak antar nilai terukur dengan nilai rata-rata kelompok. Jarak dihitung dengan menggunakan Persamaan (1) juga. Jumlah kelompok yang diambil dibatasi berdasarkan sebuah nilai ambang batas (threshold) jarak yang ditentukan.

4. Map matching
Hasil perkiraan posisi yang dihasilkan berpeluang untuk mengalami kesalahan seperti yang ditunjukkan pada Gambar 8. Posisi perkiraan dapat berada pada posisi yang tidak mungkin terjadi, misalnya pada dinding (B) atau di luar ruangan (C). Oleh sebab itu dibutuhkan sebuah mekanisme, yang disebut map matching, untuk memetakan hasil tersebut pada area yang memungkinkan (A).

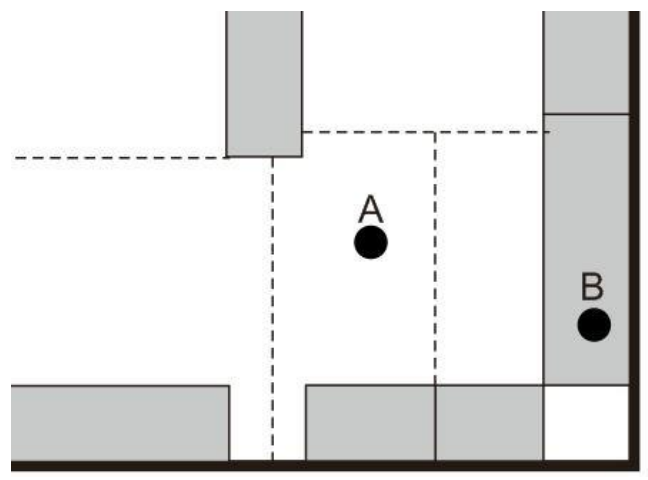

Gambar 8 Kemungkinan posisi hasil perkiraan

5. Probabilitas berdasarkan rute pengunjung

Rute yang dilalui para pengunjung dapat membentuk suatu pola yang dapat dimanfaatkan. Pada Gambar 6 ditunjukkan salah satu kemungkinan rute yang dilalui oleh pengunjung. Rute tersebut dapat memberikan nilai probabilitas suatu area akan dikunjungi setelah area tertentu.

6. Jumlah dan peletakan AP

Penentuan jumlah AP terkait dengan aspek ekonomi dan akurasi. Peningkatan jumlah AP akan meningkatkan akurasi [17], namun akan meningkatkan biaya. Penentuan letak pemasangan AP juga akan menentukan tingkat akurasi penentuan posisi [18]. Dari sisi komunikasi, peletakan AP diatur dengan tujuan untuk memaksimalkan jangkauan dengan meminimalkan overlap antar AP. Namun untuk kebutuhan SPP justru dibutuhkan overlap antar AP. Dengan demikian dibutuhkan optimasi jumlah dan peletakan AP.

7. Perbedaan pembacaan RSSI oleh beberapa jenis chipset Dalam [19] dikemukakan mengenai salah satu tantangan yang dihadapi dalam mengembangkan SPP berbasis WLAN yaitu mengenai perbedaan pembacaan RSSI oleh beberapa jenis chipset. Perbedaan pembacaan tersebut dapat menghasilkan perbedaan hasil penentuan posisi oleh beberapa perangkat.

\section{KESIMPULAN}

Sistem penentuan posisi di dalam ruangan dapat dikembangkan untuk kebutuhan museum. Proses pemilihan komponen SPP harus mempertimbangkan berbagai kebutuhan dan kondisi museum. Proses yang telah dilakukan memberikan hasil pemilihan komponen arsitektur yaitu menggunakan teknologi WLAN dengan teknik scene analysis berbasis RSSI yang memberikan output berupa informasi posisi absolut. 


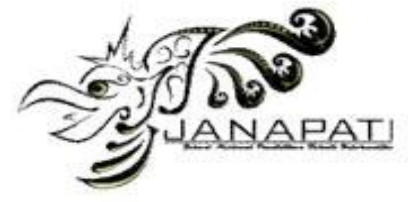

Setelah melakukan proses pemilihan komponen, penelitian lanjutan adalah implementasi sistem pada museum dan dilakukan pengujian akurasi dan presisi serta efek filtering dan clustering terhadap waktu komputasi.

\section{REFERENCES}

[1] B. Schilit, N. Adams, and R. Want, "Context-aware computing applications," in Mobile Computing Systems and Applications, 1994. WMCSA 1994. First Workshop on. IEEE, 1994, pp. 85-90.

[2] A. M. Ladd, K. E. Bekris, A. P. Rudys, D. S. Wallach, and L. E. Kavraki, "On the feasibility of using wireless ethernet for indoor localization," IEEE Transactions on Robotics and Automation, vol. 20, no. 3, pp. 555-559, 2004.

[3] J. Xiao, Z. Liu, Y. Yang, D. Liu, and X. Han, "Comparison and analysis of indoor wireless positioning techniques," in Computer Science and Service System (CSSS), 2011 International Conference on. IEEE, 2011, pp. 293-296.

[4] H. Liu, H. Darabi, P. Banerjee, and J. Liu, "Survey of wireless indoor positioning techniques and systems," Systems, Man, and Cybernetics, Part C: Applications and Reviews, IEEE Transactions on, vol. 37, no. 6, pp. 1067-1080, 2007.

[5] Y. Wang, X. Jia, H. Lee, and G. Li, "An indoors wireless positioning system based on wireless local area network infrastructure," in 6th Int. Symp. on Satellite Navigation Technology Including Mobile Positioning \& Location Services, no. 54, 2003.

[6] J. Hightower and G. Borriello, "Location systems for ubiquitous computing," Computer, vol. 34, no. 8, pp. 57-66, Aug 2001.

[7] I. Guvenc and C.-C. Chong, "A survey on TOA based wireless localization and NLOS mitigation techniques," IEEE Communications Surveys Tutorials, vol. 11, no. 3, 2009.

[8] C. Esposito and M. Ficco, "Deployment of rss-based indoor positioning systems," International Journal of Wireless Information Networks, vol. 18, no. 4, pp. 224-242, 2011.

[9] E. Aitenbichler and M. Muhlhauser, "An ir local positioning system for smart items and devices," in Distributed Computing Systems workshops, 2003. Proceedings. 23rd International Conference on. IEEE, 2003, pp. 334-339.
ISSN 2089-8673

Jurnal Nasional Pendidikan Teknik Informatika (JANAPATI)

Volume 3, Nomor 3, Desember 2014

[10] R. Want, A. Hopper, V. Falcao, and J. Gibbons, "The active badge location system," ACM Transactions on Information Systems (TOIS), vol. 10, no. 1, pp. 91-102, 1992.

[11] J. Hallberg, M. Nilsson, and K. Synnes, "Positioning with bluetooth," in Telecommunications, 2003. ICT 2003. 10th International Conference on, vol. 2. IEEE, 2003, pp. 954-958.

[12] P. Bahl and V. N. Padmanabhan, "Radar: An in-building rf-based user location and tracking system," in INFOCOM 2000. Nineteenth Annual Joint Conference of the IEEE Computer and Communications Societies. Proceedings. IEEE, vol. 2. Ieee, 2000, pp. 775-784.

[13] L. M. Ni, Y. Liu, Y. C. Lau, and A. P. Patil, "Landmarc: indoor location sensing using active rfid," Wireless networks, vol. 10, no. 6, pp. $701-$ $710,2004$.

[14] X. An, J. Wang, R. V. Prasad, and I. Niemegeers, “Opt: online person tracking system for context-awareness in wireless personal network," in Proceedings of the 2nd international workshop on Multi-hop ad hoc networks: from theory to reality. ACM, 2006, pp. 47-54.

[15] T.-N. Lin and P.-C. Lin, "Performance comparison of indoor positioning techniques based on location fingerprinting in wireless networks," in Wireless Networks, Communications and Mobile Computing, 2005 International Conference on, vol. 2. IEEE, 2005, pp. 1569-1574.

[16] Y. Zhao, H. Zhou, M. Li, and R. Kong, "Implementation of indoor positioning system based on location fingerprinting in wireless networks," in Wireless Communications, Networking and Mobile Computing, 2008. WiCOM'08. 4th International Conference on. IEEE, 2008, pp. 1-4.

[17] Z. Yang and Y. Liu, "Quality of trilateration: Confidence-based iterative localization," Parallel and Distributed Systems, IEEE Transactions on, vol. 21, no. 5, pp. 631-640, 2010.

[18] R. Priwgharm and P. Chemtanomwong, "A comparative study on indoor localization based on rssi measurement in wireless sensor network," in Computer Science and Software Engineering (JCSSE), 2011 Eighth International Joint Conference on. IEEE, 2011, pp. 1-6.

[19] G. Lui, T. Gallagher, B. Li, A. G. Dempster, and C. Rizos, "Differences in rssi readings made by different wi-fi chipsets: A limitation of wlan localization," in Localization and GNSS (ICL-GNSS), 2011 International Conference on. IEEE, 2011, pp. 53-57 